\title{
Má učení papežů o sportu vliv na teology v ČR? (analýza výsledlkư výzkumu) \\ Vojtěch Svoboda
}

\section{Úvod}

Popularita sportu je již několik desítek let nepřehlédnutelným rysem společnosti. To je jedním $z$ důvodů, proč mu ve svých projevech věnovala značný prostor také řada papežů. První část studie přibližuje způsob, jakým byl sport hodnocen v textech Jana Pavla II. a Benedikta XVI., kteří mu věnovali největší pozornost. Ve druhé části předkládá autor sedm otázek týkajících se těla a sportu teologům na území České republiky. Cílem textu je poskytnout srovnání těchto dvou typů výpovědí a tímto způsobem zjistit př́ípadné rozdíly v otázce teologického hodnocení sportu. ${ }^{1}$

\section{Cíl sondy, problémové okruhy a metodika}

První část této studie popisuje zpo̊sob, jakým byl sport hodnocen papežem Janem Pavlem II. a Benediktem XVI. Ti mu věnovali za svého pontifikátu i před ním značný prostor. Jejich vyjádření tak může být považováno za jedno z východisek pro novou teologickou disciplínu - teologii sportu. Základním zdrojem pro popis hodnocení sportu papežem Janem Pavlem II. jsou jeho kázání, proslovy při audiencích, sportovních událostech a dopisy z let 1978-2005 shrnuté ve sborníku The Pastoral Messages (Homilies, Angelus Messages, Speeches, Letters) of Pope John Paul II That Refer To Sport (1978-2005). Informace o hodnocení sportu Benediktem XVI. jsou čerpány především ze studie Sporting Activity in the Thought of Joseph Ratzinger/Benedict XVI. ${ }^{2}$

Druhá část přibližuje výpovědi současných teologů na území České republiky. Za tímto účelem byl učiněn výběr dostupných teologických autorit včetně odpovědných osob katolické církve u nás, některých profesorů, docentů a doktorů teologických fakult českých univerzit (Teologická fakulta Jihočeské univerzity v Českých Budějovicích, Katolická teologická fakulta, Evangelická teologická fakulta a Husitská teologická fakulta Karlovy univerzity v Praze, Cyrilometodějská teologická fakulta Palackého univerzity v Olomouci). Výzkumu se zúčastnili také dva katoličtí biskupové. Cílem této části výzkumu bylo prostřednictvím získaných odpovědí zjistit, jakým

1 Článek vznikl jako jeden z výstupů dvouletého projektu Katolická teologie sportu (reg. č. 115/2013/H); projekt byl finančně podpořen Grantovou agenturou Jihočeské univerzity.

2 Joseph CLEMENS, Sporting Activity in the Thought of Joseph Ratzinger/Benedict XVI., text zaslaný prostřednictvím emailové komunikace K. Lixeym, LC, který byl v letech 2004-2012 vedoucím oddělení Církev a sport Papežské rady pro laiky. 
způsobem respondenti vnímají lidské tělo a sport jako jeden z masových fenoménů současné doby. Pohled křestanského vyznání na tělesnou kulturu prošel v historii značným vývojem. Tento výzkum pomáhá objasnit, jaká je povaha tohoto vztahu v České republice v současnosti. Autor se domnívá, že vnímání lidského těla může být chápáno jako obecnější rámec pro hodnocení sportu. Proto jsou první otázky zaměřeny na tělo z pohledu teologické antropologie, další se již týkají sportu jako takového.

Z původního počtu 42 oslovených, se samotného výzkumu zúčastnilo 23 respondentů. Mezi respondenty bylo 5 osob s magisterským vzděláním, 6 doktorů, 7 docentů a 5 profesorů. Až na 2 dotázané působí respondenti na českých univerzitách jako interní nebo externí přednášející. 3 respondenti zastávají biskupský úřad. Důvodem k neúčasti 10 dotázaných bylo v některém př́ípadě shledání tématu jako nepodstatného, někteří se necítili oprávněni vyjadřovat svůj názor či považovali otázky za příliš nejednoznačné. Zbývající počet dotazovaných na prosbu o účast ve výzkumu nereagoval, přičemž v 5 př́ipadech komunikace skončila po obdržení otázek.

Za základní výzkumnou metodu byla zvolena forma strukturovaného dotazování, jež probíhalo prostřednictvím osobní, telefonické i elektronické komunikace. Sběr dat a další komunikace byly uskutečněny ve druhé polovině roku 2014, kdy byly účastníkům položeny následující otázky:

1) Co je lidské tělo?

2) Jaký je účel těla v tomto světě?

3) Co značí Kristovo zmrtvýchvstalé tělo současně s jeho slibem o povznesení našich těl?

4) Lze oddělit tělo a duši?

Jakým způsobem lze uchopit skutečnost nehmotné duše v materiálním těle?

5) Jakou roli a v jakých rovinách hraje tělesný pohyb pro křestana (spirituální, biologická, sociální atd.)?

Jaký je Váš pohled na sport z hlediska duchovní praxe? Lze jej pokládat za formu snahy přiblížit se Bohu?

6) Jaký je Váš pohled na sport v jeho pozitivních i negativních aspektech?

7) Pozorujete deficit v teologickém zkoumání těla, tělesného pohybu a fenoménu sportu?

Zvolená metoda patří do oblasti smíšeného výzkumu, v němž autor kombinuje aspekty kvalitativního a kvantitativního výzkumu. Tento typ umožňuje lepší pochopení výzkumného tématu než volba jednoho z přístupů. Sběr dat formou strukturovaného dotazování se opíral o metody kvantitativní, analýza dat a jejich kategorizování pak odpovídá pravidlům výzkumu kvalitativního. Interpretační snahou bylo najít společné rysy odpovědí a vytvořit tak kategorie, které se ve výpovědích nacházely.

Cílem této studie je poskytnout možnost srovnání dvou typů výpovědí, hodnocení sportu uvedenými papeži na základě jejich listů, dopisů a projevů a obdobné hodnocení současnými teology. Zatímco v př́padě dotazníků je možné použít přímé odpovědi nebo jejich pasáže, papežská vyjádření tento postup neumožňují. Proto se autor pokusil zvýraznit prvky a myšlenky, které se v textech objevovaly nejčastěji. Interpretací papežského hodnocení sportu se autor zabýval již ve své diplomové práci. ${ }^{3}$ Studie na tento text neprrímo navazuje.

3 Vojtěch SVOBODA, Teologie a filosofie sportu se zretelem $k$ americkému fotbalu, diplomová práce, Jihočeská univerzita v Českých 


\section{Sport očima papežů}

Pro představení postoje papežů ke sportu autor zvolil Jana Pavla II. a Benedikta XVI., kteří mu věnovali ve svých textech největší prostor. Část textů Benedikta XVI. pochází z období před jeho pontifikátem. Klíčem pro pochopení následujících papežských vyjádření je křestanská vize člověka. Dle této nauky, založené na události stvoření $\mathrm{v}$ knize Genesis, je člověk stvořen $\mathrm{k}$ obrazu Božímu (Gn 1,26-28). Současně byl stvořen jako jednota duše a těla. Bůh stvořil obě tyto části a uznal je za dobré (Gn 1,31). Nikoliv jednotlivě tělo anebo duše, ale pouze obě tyto složky dohromady skládají celého člověka. Agregaci duše a těla tak lze považovat za esenciální cíl člověka a jejich oddělování je nutné považovat za špatné. Pouze tak může korespondovat stvoření $\mathrm{k}$ Božímu obrazu s konkrétní lidskou existencí.

\section{Jan Pavel II.}

Existuje řada pramenů, které potvrzují ryze kladný vztah papeže Jana Pavla II. ke sportu včetně bohaté osobní zkušenosti. ${ }^{4} \mathrm{O}$ jeho pozitivním hodnocení se lze informovat také z počtu sportovních událostí, kterých se během svého pontifikátu zúčastnil. ${ }^{5}$ Při těchto prríležitostech pronášel proslovy, jimiž šíril poselství církve také do sportovního světa. Ačkoliv papež nevypracoval př́mo teologii sportu, jeho početná sdělení a vyjádření patří $\mathrm{k}$ základům, o které se tato mladá disciplína mủže opřít. ${ }^{6} \mathrm{~V}$ textech zabývajících se sportem často vyzdvihoval určité prvky, které tak lze považovat za jádro jeho sportovně-teologických úvah. Kromě harmonického rozvoje člověka zdưrazňoval především sport jako prostředek $\mathrm{k}$ překonání hranic jak na rovině individuální, tak na rovině globální.

Sport bývá někdy chápán především jako rozvijení tělesné složky člověka či jako nástroj upevnění fyzického zdraví. Papež si tohoto prvku velice váží. Současně však také podotýká, že sport rozvijí člověka v celém jeho rozměru zahrnujícím tělo i duši: „Hráč nenachází potřebnou relaxaci pouze na úrovni těla, nezískává jen více ohebnosti, dovedností či vytrvalosti, neposiluje pouze své zdraví, ale roste také energie jeho ducha..."

„Ano, jako mnoho dalších sportů, fotbal může pozvednout člověka. ${ }^{\text {“8 }}$

Nejpodstatnější př́nos sportu však shledává především v jeho mezilidské rovině. Toto pozitivum se neprojevuje pouze na úrovni individuálních vztahů, ale může vést k překonání bariér mezi celými národy: „Sport může jistě přispět k pomoci účastníkům poznat se lépe, ocenit jeden druhého a zažít solidaritu navzdory hranicím, a to právě na společném základě jejich stejných lidských a sportovních kvalit."

Budějovicích, České Budějovice, 2011.

4 Jako zajímavost může působit osobní sdělení současného vedoucího oddělení Církev a Sport Papežské rady pro laiky S. C. de Pereze, který autora článku při návštěvě Vatikánu v listopadu 2013 informoval o tom, že papež Jan Pavel II. nechal přebudovat místní heliport na tenisový kurt.

5120 sportovních událostí. Osobní sdělení S. C. de Pereze, listopad 2013.

6 Texty Jana Pavla II., které jsou použity v tomto článku, pocházejí z Kevin LIXEY - Norbert MÜLLER - Cornelius SCHÄFER, The Pastoral Messages (Homilies, Angelus Messages, Speeches, Letters) of Pope John Paul II That Refer To Sport (1978-2005), Vatican: John Paul II Sports Foundation, 2012.

7 JOHN PAUL II, Human and Sporting Qualities Make Men Brothers. Představitelům setkání UEFA v Rímě 20. června 1980. Vlastní překlad.

8 Tamtéž.

9 Tamtéž. 
Či jinde: „At̉ je vaše setkání symbolickým znakem pro celou společnost a předehrou $k$ této nové době, ve které národy ,nepozdvihnou meč proti pronárodu (Iz 2,4).“10

Mezi neodmyslitelné vlastnosti sportu patři jeho soutěživost. Papež často nabádal k jejímu očištování pro zachování správné - člověku zdravé - podoby: „... pomoc budovat občanskou společnost, kde je antagonismus nahrazen zdravou soutěží, kde je setkání preferováno před konfliktem a čestná výzva před zlomyslnou opozicí. ${ }^{\text {"11 }}$

Současně s pozitivy však Jan Pavel II. nezapomíná upozornit na nebezpečí, která svět sportu ohrožují. Mezi nejčastěji skloňované patří jeho komercionalizace, korupce a další: „... z obsedantní posedlosti ziskem $\mathrm{z}$ komercionalizace téměř každého aspektu sportu, $\mathrm{z}$ excesivního důrazu na atletické a technické vyčerpání, od používání dopingu a dalších forem podvodu k násilí. “"12

\section{Benedikt XVI.}

Také papež Benedikt XVI. poskytuje řadu výpovědí vhodných pro teologickou reflexi sportu. Biskup Clémens uvádí, že během prvních dvou a půl let svého pontifikátu se papež dotkl tématu sportu ve více než padesáti př́padech. ${ }^{13}$ Jak sám vysvětluje: „Během pontifikátu papeže Benedikta XVI. i nadále pokračuje zájem Všeobecné církve o svět sportu, nebở usiluje o dialog s proslulými sportovními institucemi na mezinárodní úrovni při současné obnově pastorační činnosti ve sportu a skrze něj..." ${ }^{\text {14 }}$

V souvislosti s kopanou podtrhuje kardinál Ratzinger již v období před svým pontifikátem její globální ráz a současně masivní vliv na člověka po celém světě: „Fotbal se stal globální událostí, která přenáší lidi z celého světa napříč všemi hranicemi do jednoho a téhož ,místa duše', kde jsou spojeni nadějí, napětím, vášní a radostí. Jiná událost na zemi může jen velmi těžce dosáhnout podobného a natolik rozširréeného efektu. ${ }^{\text {"15 }}$

Skrze rozbor sportu dospívá k jeho radikální svobodě umožňující vystoupit z nutnosti každodenního života. $V$ tomto smyslu sport označuje za předzvěst ráje: „... sport se stává jistou předzvěstí ráje: vystoupení $\mathrm{z}$ otrocké vážnosti a starostí našeho každodenního života do svobodné opravdovosti něčeho, co by nemělo být vážné, a je tudíž překrásné. Tímto způsobem sport překračuje každodenní život. “"16

Benedikt XVI. opakovaně zdůrazňuje, že svoboda v rámci sportu není absolutní, nýbrž je založe-

10 JOHN PAUL II, The Most Authentic Dimension of Sport: To Create a New "Civilisation of Love", homilie na Olympijském stadionu v Římě 12. května 1989. Vlastní překlad.

11 JOHN PAUL II, Jubilee of Sports People Address of John Paul II to the International Convention on the Theme: "During The Time of the Jubilee: The Face and Soul of Sport”, 28. října 2000. Vlastní prreklad.

12 JOHN PAUL II, Stadium Blessing Marks Start of International Playoffs: Pope John Paul II Inaugurates 'ITALIA 90’ Cup, 31. května 1990. Vlastní překlad.

13 Joseph CLEMENS, Sporting Activity in the Thought of Joseph Ratzinger/Benedict XVI.

14 () Joseph CLEMENS, Sport in the Magisterium of Benedict XVI (on-line), dostupné na: http://thesportjournal.org/article/sport-in-the-magisterium-of-benedict-xvi/, aktualizace dne 28. 2. 2013, citováno dne 14. 4. 2015. Vlastní překlad.

15 (C) Joseph RATZINGER, Football Can Be More Than Just Entertainment (on-line), dostupné na: http://freeforumzone.leonardo.it/ discussione.aspx?idd=354533, citováno dne 15. 3. 2015. Vlastní překlad.

16 Tamtéž. 
ná na pravidlech. ${ }^{17}$ Sport se tak stává školou života, která učí skrze trénink sebekontrole, skrze niž může sportovec dosáhnout svobody. ${ }^{18}$ Mezi další prínosy sportu patř́i spolupráce. Sport, zejména kolektivní, nabízí společný cíl přispívající k budování celého společenství: „Sport, provozovaný s nadšením a eticky, se zejména pro mládež stává cvičištěm zdravé soutěže a fyzického zušlechtění, školou formování v oblasti lidských a duchovních hodnot, výsadním prostř̌edkem pro osobní růst a kontakt se společností. ${ }^{\text {"19 }}$

Obdobně v dopise kardinálu Rylkovi píše: „V současnosti, kdy je evidentní potřeba vzdělávat nové generace, zůstává pro církev nutné, aby pokračovala v podpoře sportování mladých a činila pozitivní také úroveň soutěže... ${ }^{\text {"20 }}$

Ve svém proslovu k rakouskému národnímu lyžařskému týmu papež shrnuje, že: „Pokud je sport provozován ve správném duchu a s respektem $\mathrm{k}$ důstojnosti člověka, napomáhá $\mathrm{k}$ rozvoji člověka. Sport jedinci pomáhá k rozpoznání vlastních schopností, talentu a svého života jako Božího daru. I když je provozován na vysoké úrovni, je důležité udržet vnitřní harmonii mezi tělem a duchem, aby nedošlo $\mathrm{k}$ její redukci na pouhé dosahování výsledků. ${ }^{21}$

\section{Odpovědi k okruhu: Lidské tělo - jednota a rozmanitost}

Analýza výzkumu počíná přiblížením odpovědí na první otázku: „Co je lidské tělo?“Jakým způsobem je vnímána bytostná materiální existence člověka? Zodpovězení této otázky se jeví jako výchozí bod pro možnost další výpovědi o tělu.

Nejčastější odpovědi zdůrazňovaly psychosociální jednotu člověka. V této souvislosti odkazuje R1, profesor a evangelický duchovní, na myšlenky K. Bartha, když odpovídá: „Člověk je stvořen $\mathrm{v}$ psychosomatické jednotě, jako duše a tělo, duše má určitý primát..., ale nepředstavitelné jsou jak tělo bez duše, tak duše bez těla.“”

Podnětnou odpověd podává také R2, laik přednášející na Teologické fakultě Jihočeské univerzity v Českých Budějovicích: „Lidské tělo je skutečně chrám ducha, ,nástroj' duše a ducha pro činění ve hmotné úrovni. Tělo se má $\mathrm{k}$ vy̌šším rovinám člověka přibližně asi tak, jako se má kostra $\mathrm{k}$,jemnějším‘ soustavám těla, jako jsou např́klad svalstvo, nervy atd. Lidské tělo je výtvorem úžasné inteligence, která na jeho vytváření vlastně neustále pracuje, jak můžeme vidět $\mathrm{z}$ evoluce člověka. Je mu dáno proto, aby s ním mohl působit zde na zemi a tím ji (i sama sebe) přetvářet $\mathrm{k}$ čím dál větší dokonalosti.“

Ze všech odpovědí byl patrný obdiv $k$ tělu jako Bohem stvořenému a pozemsky dokonalému. Nejčastější odpověd’ na tuto otázku se vztahovala $\mathrm{k}$ jednotě psýché a sóma, dvou pojmů, $\mathrm{s}$ ni-

17 Srov. ( ) Joseph CLEMENS, Philosophical Foundations of the Sporting Phenomenon (on-line), dostupné na: http://thesportjournal.org/ article/sport-in-the-magisterium-of-benedict-xvi/, citováno dne 16. 3. 2015. Vlastní překlad.

18 Srov. (C) Joseph RATZINGER, Football Can Be More Than Just Entertainment.

19 BENEDICT XVI, L'Osservatore Romano, Speech to the Participants of the World Swimming Championship, 2009. Vlastní překlad.

20 (c) BENEDICT XVI, Message of His Holiness Benedict XVI To Cardinal Stanislaw Rylko, President of the Pontificial Council For the Laity on the Occasion of the International Study Seminar on: "Sport, Education, Faith: For a New Season for the Catholic Sports Movement" (on-line), dostupné na: http://www.vatican.va/holy_father/benedict_xvi/messages/pont-messages/2009/documents/hf_ben-xvi_mes_20091103_rylko-sport_en.html, citováno dne 15.3. 2015. Vlastní překlad.

21 () BENEDICT XVI, Sport Must Not Be Reduced to a Mere Search for Results (on-line), dostupné na: http://www.freeforumzone.com/ discussione.aspx?idd=354494\&p=132, citováno dne 20. 3. 2015. Vlastní překlad. 
miž teologie obvykle pracuje. Člověk je v křestanské tradici obvykle chápán jako jednota tělesné, duševní a duchovní složky. Důraz na zahrnování třetí složky však prochází určitým vývojem a duch v člověku se tak stal předmětem mnoha diskuzí. ${ }^{22}$ Poskytuje však toto antropologické dělení skutečnou odpověd’ na výše položenou otázku?

Druhá otázka, „Jaký je účel těla v tomto světě?“, navazuje na předchozí. Člověk si podmanil zemi v těle, které je v porovnání s tělem zvířat bezbranné. Přesto však díky své variabilitě umožňuje život po celé planetě. Tělo umožňuje naplňovat nejrůznější potřeby a plány člověka. K řadě $\mathrm{z}$ nich jej samo motivuje. Jakým způsobem odpovídají teologové na otázku po účelu lidského těla?

Až na výjimky uváděla většina dotázaných dva podstatné účely lidského těla. Prvním z nich je komunikace s ostatními. Tělo tak bývá chápáno jako prostředník duše pro její setkání s tímto světem a současně také dalšími dušemi.

R3, docent katolického vyznání, v této souvislosti tvrdí: „Jestliže chápu člověka jako nejnižší z duchovních bytostí, pak je tělo člověka vlastně most mezi duchovní stránkou člověka a hmotným světem."

Dalším často zdůrazňovaným účelem je existence našeho těla jako forma služby Bohu. Ten bývá podkládán biblickým stvořením člověka k obrazu Božímu.

R4, profesor a evangelický duchovní, v této souvislosti konstatuje: „... Všechno, co v těle konáme (práce, rodina etc.), má sloužit našim bližním, k Boží oslavě a všechno smíme prožívat sub specie aeternitatis."

Snad nejsilněji v tomto smyslu komentuje člen Pravoslavné církevní obce České Budějovice a Jindřichův Hradec, R5: „Dojít spolu s lidskou duší a duchem k theozi - ,zbožštěníc“. Tvrzení však doplňuje vysvětlením, že se člověk nestane bohem, podobně jako se železo přitisknuté k magnetu nestane magnetem, ale získá určitým zpơsobem jeho vlastnosti.

Mezi odpověd’mi se často opakovala také nutnost naší smrti. Docent katolického vyznání, R6, v tomto bodu připomíná: „... nauky prvních koncilů - zejména Efezu a Chalcedonu - jednoznačně ukazují na to, že ,tělo', resp. reálná ,fyzická‘ či ,lidskác existence samotného Krista, byla zdůrazněna jako zcela zásadní záležitost: bez jeho fyzického utrpení a smrti bychom nemohli být spaseni. Z toho pro mě vyplývá, že tělo má zásadní význam: musíme zemřít, abychom po smrti žili s Kristem - a to je cíl resp. účel lidského těla..., člověk musí zemřít, aby mohl po své smrti žít s Kristem. Smrt tak může být chápána jako konečný účel lidského těla v naději na posmrtné vzkříšení.“

Smrt a vzkříšení Ježíše Nazaretského jsou jádrem křestanského učení. Vírou ve zmrtvýchvstání těla se zabývá podstatná část křest’anské dogmatiky. Z tohoto úhlu pohledu nabývá značné důležitosti také eschatologický rozměr lidské existence. Třetí otázka tak tvoří logické pokračování výpovědí. V souvislosti s Kristovým tělem po jeho vzkř́íšení se v teologických kruzích obvykle hovoří o odlišné ontologické rovině existence. V tomto smyslu také odpovídá většina dotázaných.

22 O duchu hovoří biblická tradice termíny ruach či pneuma. Termín je často používaný například apoštolem Pavlem, pozornosti se mu dostává zejména na osmém ekumenickém koncilu. 
R4 hovoří takto: „Zmrtvýchvstalé Kristovo tělo nepodléhá fyziologicko-biologickým zákonitostem časoprostoru a Kristovo vzkřrišení otvírá eschatologickou perspektivu participace na Kristově oslaveném těle ( $1 \mathrm{~K} 15,20-58)$.“

R3 pokračuje: „Jde o doklad toho, že pro Boha není hmota nic nečistého, takže se skrze Kristovo lidství (včetně jeho tělesnosti) mohla spojit i s božstvím. Zároveň (mluvíme-li o těle po vzkřrišení) je to reálný (apoštolové se ho dotýkali) doklad, že př́islib oslavení člověka včetně jeho tělesnosti není jen metafora nebo nedorozumění.“

Někteří z dotázaných odpovídali v širším společenském kontextu vzkříšení. Zde se stává pravým jádrem nauky o vzkříšení společenská rovina této události, tedy povznesení všech lidí, celého lidstva. V tomto smyslu odpovídá R7, biskup Církve československé husitské: „Značí realitu vzkříšení, které se týká člověka v jeho celosti. Jedná se o zaslíbení vzkříšení pro všechny, kteří přijmou Kristovu cestu.“

R2 říká: „Kristovo vzkřrišené tělo je výrazem jeho vítězství nad smrtí. Kristus svou duchovní silou, svým životem, porazil síly smrti a vymanil se z jejich vlivu. Tím se i jeho tělo stalo nezávislým na silách smrti a bylo povýšeno do úrovně nesmrtelnosti... Při vyslechnutí Kristovy výzvy k jeho následování budeme Jeho silou a životem postupně naplňováni natolik, že jednou budeme z vlivu smrti také vymaněni a naše tělo jim již nebude podléhat. To je vzkř́išení.“

Tělo a duše jsou obvykle považovány za základní složky člověka. $V$ době od narození do smrti můžeme mezi člověka a jeho tělo položit rovnítko. Přesto antická i biblická tradice předpokládá, že lidské tělo se od těl ostatních živých tvorů neliší pouze svou strukturou, ale také svou kvalitou či podstatou, kterou tradičně nazýváme pojmem „duše“. Pokud bude o člověku činěna výpověd’ z hlediska zmíněné antropologie, bývá obvykle používán termín duše jako ta část člověka, která nepodléhá zániku těla. Další otázka se zabývala právě těmito dvěma složkami a jejich vzájemným vztahem.

R8, katolický docent, vysvětluje, jakým způsobem bylo na tuto otázku pohlíženo v historii: „Vztah duše (ducha) a těla je ovšem předmětem dalekosáhlých diskusí trvajících už několik tisíc let. $V$ těchto diskusích se setkáváme s několika pohledy na vztah tělo-duše: 1. Aristotelsko-tomistický = duše je ,forma formans corporis 'či dle Boëthia ,substantia spiritualis, identice permanens, causa et substratum actuum psychicorum; 2. Biblicko-orientální = duše je oživující princip (nišmat chajjím $=$ dech života); 3 . Materialistický = duše je totožná s centrální nervovou soustavou.“

Mezi odpověd’mi panovala $\mathrm{v}$ tomto př́padě jasná shoda. Nikdo $\mathrm{z}$ dotazovaných nepřipustil reálné oddělení těla a duše za života člověka. Lidská bytost je v návaznosti na první otázku chápána jako kompozitum, $\mathrm{v}$ jehož rámci je duše v určitém směru považována za hybnou složku hmotného těla. Skutečné oddělení těchto složek je dle všech dotázaných možné pouze po smrti člověka.

Takto odpovídá např́klad R5: „Lidový výraz duše se vlastně vztahuje $k$ duchu člověka, ..., ten se odděluje od těla v okamžiku smrti... Duše je oživující princip, který rovněž ve smrti tělo opouští, což se projeví právě únikem života a postupným rozpadem. Skutečnost nehmotné duše (resp. Ducha) v materiálním těle uchopit nelze a ani to není zapotřebí..." 
Někteř́ z dotázaných však naznačili možnost určitého „rozvolnění“ tohoto vztahu. R9, biskup katolické církve, považuje svůj postoj k této problematice za velmi zdráhavý a konstatuje, že na úplné oddělení duše a těla nevěří, avšak připouští právě možnost jistého „rozvolnění“. Tuto možnost uznává také další z biskupů, R10.

Velmi zajímavé vysvětlení této v jistém smyslu duality poskytuje R2: „... Nehmotnost duše a materiální tělo možná zní až zbytečně protikladně. Když si představíme či řekneme, že tělo je zhmotnělý, zkondenzovaný duch či zhmotnělá ,část' duše, či naopak, že duše je velice jemná, produchovnělá (vědecky zatím neprobádatelná) hmota, tak už to tak rozporuplně a dualisticky nezní..."

Duše je chápána jako oživující princip, bez kterého tělo zaniká. Současně zůstává identita člověka pouze v jeho plnosti. Obvyklá odpověd' hovořila o zániku těla po oddělení duše. Vysvětlení opačným způsobem poskytl R3: „Lidská duše je uzpůsobena tak, aby dokázala komunikovat a nabývat nových vědomostí prostřednictvím tělesných funkcí. Po odnětí těla je tedy jaksi solipsisticky uvězněna v sobě. Smysl nesmrtelnosti duše ve smyslu přežití smrti těla dává pouze Bůh, který umožňuje separované duši (po smrti a před vzkř́išením) komunikovat (tím, že jakoby svou činností supluje chybějící mediaci tělesnosti)..."

\section{Odpovědi k okruhu: Sport - cesta k Bohu?}

V souvislosti se sportem se ve společnosti často hovoří o jeho přínosu pro tělesné zdraví člověka. Sport jako takový, např. v antickém Řecku, pravděpodobně vznikal na náboženském základě. Stále také existují náboženství, pro která je pohyb (často ve formě tance či rituálního souboje) přímým nástrojem ke spirituálnímu prožitku. I v dnešní moderní společnosti existuje množství případů, kdy se sportovci dostávají v průběhu svého výkonu až do pozměněného stavu vědomí. Podle vlastních slov zažívají zkušenosti, které jsou spíše duchovního charakteru. ${ }^{23}$

Otázku možného transcendentního prvku sportu lze v současnosti považovat za jedno z hlavních témat teologie sportu. ${ }^{24}$ Odpovědi na následující otázky mají za úkol osvětlit, jaký postoj zaujímají $\mathrm{k}$ této problematice čeští teologové.

Dle R8 vede sport k: „... nalezení, přijetí a rozvinutí sebe sama, ba dokonce k sebetranscendenci. Pokud je možné toto sebepřijetí a seberozvoj chápat jako cestu k Bohu, pak také sportovní výkon směruje k této cestě.“

Více než polovina dotázaných možnost určitého duchovního náboje ve sportu nepopírala. Současně respondenti uváděli určité podmínky k tomu, aby mohla být tato spiritualita umožněná. Jednou z frekventovaných podmínek tak bylo, aby sport nepřekážel spirituálním potřebám jedince.

23 Např́íklad typ zkušenosti známý jako tok (flow). Pro více informací viz Michael MURPHY - Rhea WHITE, In the Zone: Transcendent Experience in Sport, New York: Penguin Book, 1995.

24 Nepř́má diskuze se odehrává např́íklad mezi Rev. Dr. L. Harveym, který zastává „autotelickou“ teorii sportu, a Rev. Dr. R. Ellisem, který vyjadřuje názor, že sport pomáhá v moderní společnosti naplnit potřeby, které byly dř́ve vyhrazeny (organizovanému) náboženství. Pro více informací viz Robert ELLIS, The Games People Play, Oxford: Wipf and Stock, 2014; Lincoln HARVEY, A Brief Theology of Sport, Oxford: Scm press, 2014. 
Jedna z odpovědí zněla: „Při sportu dochází k jistému sebepřekonávání se, překračování svých limitů, což je i jedním z rysů snad každé duchovní praxe. Přiměřeně provozovaný pohyb (a tedy i sport) přispívá $\mathrm{k}$ tělesné kráse a krása je nepochybně jedním $\mathrm{z}$ atributů Božích, takže sportem ke kráse a zdokonalení těla jistě může znamenat sportem k Bohu. Ovšem za předpokladu, že prostředek nebude změněn na cíl.“

R9 hodnotí úlohu sportu v životě křest’ana v první řadě z funkčního hlediska. Sport je dle něj činností, která tělu prospívá, a tak přispívá ke zdraví člověka. Správně fungující tělo je navíc zpravidla základní podmínkou pro výkon povolání, která slouží potřebným.

Zastáncem spíše neutrálního stanoviska je u této otázky R1: „Sportu se snad dotknou některé teologické etiky, ale pouze okrajově - na rozdíl třeba od umění nebo vědy i techniky. Jako takový je sport ,nábožensky neutrální, k Bohu nepřivádí ani od Boha neodvádí, pro křestana může být dobrý, ale jen relativně.“

Poněkud zdrženlivěji odpovídá k tomuto bodu R5: „Protože největšími znalci duchovního života byli pouštní otcové, můžeme vycházet $\mathrm{z}$ jejich zkušeností, že je třeba udržovat tělo alespoň v dostatečně funkčním stavu, aby se člověk mohl věnovat modlitbě a ručním pracem (živobytí). Velicí asketové ovšem ,mořili‘ tělo více, protože ze zkušenosti věděli, že síla ducha a těla jsou v nepřímé úměře. Př́lišná péče o tělo uspává duchovní život. Co se týče sportu, ten patřil do antického cirku, ale nebyl součástí duchovní teorie ani praxe.“

Jedním z témat, kterému věnovali pozornost již papežové v předkoncilním období, je etické hodnocení moderního sportu. Již papež Pius XII. na toto téma hovoří roku 1945 ve svém listě Jak může kultura sportu přispět $k$ formování mladých ${ }^{25}$ či o deset let později ve spise Ctnosti pro sportovní výchovu krestanů. ${ }^{26}$

Sport, jako aktivita přispívající k celkovému zdraví ve smyslu fyzické, psychické i sociální pohody, dnes může vyrovnávat nedostatek pohybu způsobený vývojem společnosti a způsobem života. Dalším pozitivem je bezesporu určitá schopnost překonání překážek, at vnějších, nebo vnitřních. ${ }^{27}$ Stejně jako všechna ostatní odvětví lidské činnosti i sport reflektuje tu stránku člověka, která je považována za následek jeho pádu. Cílem následující otázky bylo zjistit, jaké jsou dle dotázaných hlavní př́nosy a negativa dnešního sportu.

R5 odpovídá takto: „Člověk se naučí vnitřní kázni a vytrvalosti, což jsou dovednosti, které se mohou dobře použít, pokud se člověk rozhodne pro duchovní život. Zvláště v Sýrii používali mniši sportovní terminologii pro duchovní zápas.“

Prvek askeze na sportu oceňuje také R9. Odpovídající si však byli vědomi také řady rizik a negativ, která mohou být na sport nanesena. Co se negativních prvků ve sportu týče, docent přednášející na Teologické fakultě Jihočeské univerzity v Českých Budějovicích, R11, nepřímo hovoří o jevu, který bývá označován pojmem „občanské náboženstvi“", když vypovídá následujícím způsobem:

25 Vlastní překlad.

26 How the culture of sport can contribute to the formation of youth, in: Sport in Magisterium of Pius XII, Kevin LIXEY. Nepublikovaný text zaslaný prostřednictvím emailové komunikace Rev. Kevinem Lixeym 11. 10. 2013.

27 Jan Kassián hovoří o atletu jako ideálním vzoru a zdroji inspirace pro budoucí mnišský život. Srov. Patrick KELLY, Catholic Perspectives on Sport. From Medieval to Modern Times, New Jersey: Paulists Press, 2012, s. 103. 
„Může zde docházet i k náhražce Boha, resp. ke zbožštění sportu (sportovců), sportovního zážitku (adrenalinu) apod.“

R3 upozorňuje na záměnu cesty za cíl: „... sport je skvělá věc, ale nesmí se stát kultem zdraví, ani kultem těla, ani nesmiřitelným hnaním se za penězi nebo vyššími a vyššími výkony bez ohledu na zdraví a sociální kontext.“

Teologové tak kritizují např́klad kult těla, nepřiměřené finance a doping. Většina $\mathrm{z}$ uvedených negativních aspektů souvisí s rozvojem některých patologických rysů společnosti jako celku. Je nutné dodat, že tyto prvky jsou patrné zejména v profesionálním sportu. R2 tuto otázku uzavírá následujícím způsobem: „Sport jako metoda je de facto neutrální. Záleží na jeho využívání člověkem, na našich záměrech, cílech, ty teprve s sebou přinášejí pozitivní nebo negativní aspekty, když jsou tedy vůči něčemu vztažené."

Na závěr každého rozhovoru byl věnován prostor otázce, zda jednotliví respondenti vnímají deficit v teologickém zkoumání tohoto odvětví. Většina $z$ dotázaných (16) se vyjádřila pozitivně. Negativní stanovisko bylo vlastní pětici odpovídajících. Pouze dva uvedli, že neznají odpověd.

Připojené výpovědi hovořily o nedostatku, či dokonce dle R3: „Jednoznačně ano - přímo privaci, nejen deficit.“ Podobně vypovídá R5: „No to je téma pro celocírkevní diskusi právě v naší situaci! Že to nepřišlo dřive.“ Opačně vypovídá R12, doktor katolického vyznání: „Ne, i když je to zajímavé. Je to ale potřebné?"

\section{Závěr}

Prohlášení papežů odpovídají křestanské vizi člověka, který byl stvořen k Božímu obrazu jako neoddělitelná jednota těla a duše. Z této výchozí pozice oba uvedení papežové konstatují, že sportovní aktivita nesouvisí pouze s fyzickým rozměrem člověka, ale zasahuje celou jeho existenci. Jak př́nosy, tak negativa těchto aktivit tedy zasahují tělo i duši, které však nejsou chápány jako jednotlivé složky, nýbrž jako hlediska, ze kterých lze na člověka pohližzet. V hodnocení důsledků působení sportu na člověka panuje mezi oběma papeži shoda. Ke zřejmým pozitivům na individuální rovině patří relaxace od napětí či stereotypu každodenního života. Sport zejména tím, že podněcuje $\mathrm{k}$ sebekontrole, přispívá také $\mathrm{k}$ harmonickému rozvoji jednotlivce. Značný prostor byl věnován i interpersonálnímu působení sportu, který tak může značnou mírou přispívat k odstranění mezilidských bariér a prohloubení spolupráce nutné pro budování společnosti. Tento prvek získal značný prostor zejména v textech papeže Jana Pavla II., který jej představuje jako nástroj k překonání rozdílu nejen mezi jednotlivci, ale dokonce také mezi národy. Současný sport tak dle jeho slov může přispět k řešení globálních problémů.

Oba papežové si všímali také nebezpečí, která mohou sportovní svět provázet. Svoji pozornost však nezaměřili na negativní působení sportu na člověka, ale spíše na způsob, jakým je sport ovlivněn společností. Ta jej může poškodit především přehnaným důrazem na komercionalizaci či pěstování kultu těla a výkonu. Očištování sportu v duchu vzájemného respektu mezi jeho účastníky však může prospět vnímání soutěže jako takové. ${ }^{28}$ Otázka slučitelnosti soutěže a křes- 
tanského vyznání je tématem, kterému v posledních letech věnuje prostor stále více teologů zabývajících se také sportem..$^{29}$ Jan Pavel II. i Benedikt XVI. tak opakovaně vyjadřovali myšlenku, která je aktuální právě dnes, kdy je možné soutěž rozpoznat jako jeden $\mathrm{z}$ hlavních vzorů života společnosti či světonázoru.

Druhá část studie představuje způsob, jakým odpovídali čeští teologové na konkrétní otázky týkající se těla a sportu. Zatímco v odpovědích na otázky vztahující se $\mathrm{k}$ teologické antropologii panovala převážná shoda, $v$ hodnocení sportu je možné spatřit (mnohdy značnou) různorodost. Zatímco jedna část dotázaných jej hodnotila v obdobně pozitivním duchu jako uvedení papežové, další jej shledává jako neutrální či spíše nepodstatný. Otázkou také zůstává, jakým způsobem interpretovat početnou skupinu, která svoji účast na výzkumu odmítla.

Mezi papežskými vyjádřeními a výpověd’mi českých teologů panuje shoda v otázce př́nosu sportu jednotlivci. Nejčastěji byla uváděna schopnost sebepřekonání a osvojení sebedisciplíny. Tyto vlastnosti jsou často kladeny do souvislosti s asketickou praxí. Transcendentální povaha sportu byla přiznávána pouze výjimečně, a to s odkazem na rozvoj člověka v jeho plnosti, který může být přeneseně chápán jako cesta $\mathrm{k}$ Bohu. Mezilidský rozměr sportu, který zaujímá $\mathrm{v}$ papežských textech ústřední pozici, chyběl ve vyjádření českých teologů úplně. Co se negativních prvků sportu týče, nejčastější odpověd’ varovala před jeho idolatrizací a také před přehnaným důrazem na některé jeho atributy (fyzická výkonnost, krása atp.), což mưže vést k vytvoření kultu těla či krásy.

Další rozdíl se týká negativních prvků sportu. Zatímco čeští teologové hovoří o způsobu, jakým může sport negativně ovlivnit člověka, papežská vyjádření popisují spiše poškození, která může utrpět sport ze strany lidské společnosti. Tato odlišnost poukazuje na odlišné vnímání sportu jako takového. Zatímco papežové jej vnímají jako panenský prostor náchylný $\mathrm{k}$ vnějším vlivům a velmi často také nabádají k jeho očištění, odpovědi poskytnuté českými teology jej představují spíše jako odvětví, které s sebou přináší také vlastní nebezpečí. Takové hodnocení mủže mít, dle autora, dvojí kořeny. První z nich lze vztáhnout k platónskému dualismu, který vnímá tělo jako méně hodnotné oproti nemateriální duši. Tento myšlenkový proud našel své zastánce také při formování křestanské vize osoby. Za druhý $\mathrm{z}$ kořenů tohoto postoje považuje autor takové vnímání sportu, které odkazuje především na tělesnou dimenzi člověka. Na tomto základě lze hodnotit současný sport jako aktivitu, která nemá dostatečnou hodnotu a je svým způsobem nebezpečná tomu, co je v tomto pojetí více lidské, tj. duši. ${ }^{30}$ Ačkoliv je „definitivní “ forma dualismu chápána v protikladu s křestanským modelem celistvého člověka, její prvky je $\mathrm{v}$ různých podobách možné sledovat $\mathrm{v}$ teologických úvahách např́ic celou historií církve. Nelze tedy vyloučit možnost, že se promítají také do teologického hodnocení sportu v zemi, kde tato disciplína dosud nemá pevné kořeny.

Sport je fenoménem, který zastává ve společnosti pevné postavení. Lze jej považovat za velmi podrobné vyobrazení člověka a společnosti jako takové. Převládající prvky společnosti, byṫ skryté, mohou být patrné právě $\mathrm{v}$ tomto prostoru. To přivádí $\mathrm{k}$ mylnému úsudku, že sport je člověku více nebezpečný než jiná odvětví lidského života. Dle křestanského výkladu byl člověk (i svět) stvoře-

29 Srov. (C) Jeremy TREAT, More than a Game: A Theology of Sport (on-line), dostupné na: http://tgc-documents.s3.amazonaws.com/ themelios/Themelios40.3.pdf\#page=12, citováno dne 12. 3. 2015; Peter MAIER, Christianity and Competition Workbook, Missouri: Concordia Publishing House, 2010; Shirl HOFFMAN, Good Game: Christianity and Culture of Sports, Texas: Baylor University Press, 2010; Donald DEARDORFF - John WHITE, The Image of God in Human Body: Essays on Christianity and Sports, Wales: The Edwin Mellen Press, 2008.

30 Oproti tělu, které je jako materiální pomíjivé, tedy méně hodnotné. V extrémní dualistické pozici může být tělo vnímáno dokonce jako překážka v cestě duše. 
ný Bohem jako dobrý (v celém jeho rozměru). Současně však prošel pádem a došlo k poškození všech hledisek, ze kterých může být nahlížen. Je tedy zároveň dobrý i špatný. Autor se domnívá, že stejným způsobem je nutné pohlížet také na sport. Sport je dar, který dal Bůh člověku. Tento dar v sobě jako vše lidské reflektuje hř́šnou povahu lidí.

Sport je místem aktualizace člověka a budování mezilidské lásky. Toto autor pokládá za skutečný význam poselství, které předávali papežové v textech přiblížených touto studií. Na výkladu teologických výpovědí o sportu v České republice je sice patrné pozitivní hodnocení jeho individuálního rozměru, autor se však domnívá, že je nutné obrátit pozornost také na způsob, jakým sport pomáhá překonat rozdíly mezi spoluhráči i soupeři. Teologie sportu pak bude moci nabídnout nový náhled na řadu aktuálních problémů, které nyní před církví vyvstávají.

\section{Má učení papežư o sportu vliv na teology v ČR? (analýza výsledků výzkumu)}

\section{Abstrakt}

Tato studie se zabývá teologickou reflexí sportu. V první části přibližuje způsob, jakým sport hodnotili Jan Pavel II. a Benedikt XVI. Hlavním zdrojem informací jsou v tomto bodě proslovy, dopisy a další texty, ve kterých věnovali oba papežové sportu značný prostor. Druhá část studie přináší odpovědi na otázky týkající se těla a sportu, které autor předložil vybranému vzorku teologů na území České republiky. Cílem studie je poskytnout možnost srovnání mezi těmito dvěma typy výpovědí. Mezi papežskými výpověd'mi a oslovenými teology panuje převážná shoda v otázce př́nosu sportu na úrovni jedince. Vybraná skupina teologů však neposkytuje žádnou výpověd' týkající se mezilidského či globálního aspektu sportu. Autor navrhuje zaměřit další výzkum tímto směrem.

Klíčová slova: Jan Pavel II., Benedikt XVI., teologie sportu, tělo, duše, společenství

\section{Kontakt na autora}

\section{Mgr. Vojtěch Svoboda}

Jihočeská univerzita v Českých Budějovicích

Teologická fakulta, Katedra filosofie a religionistiky

Kněžská 8, 37001 České Budějovice

svobov04@tf.jcu.cz 